\title{
Edge effects and patch size in seagrass landscapes: an experimental test using fish
}

\author{
Jane E. Jelbart ${ }^{1,3, *}$, Pauline M. $\operatorname{Ross}^{1}{ }^{1}$ Rod M. Connolly ${ }^{2}$ \\ ${ }^{1}$ University of Western Sydney, Locked Bag \#1797, Penrith DC, New South Wales 1797, Australia \\ ${ }^{2}$ Centre for Aquatic Processes \& Pollution, and School of Environmental and Applied Sciences, Griffith University, PMB 50, \\ Gold Coast Mail Centre, Queensland 9726, Australia
}

${ }^{3}$ Present address: Water and Catchment Science, New South Wales Department of Environment and Conservation, PO Box A290, Sydney South, New South Wales 1232, Australia

\begin{abstract}
Edge effects and bed size are 2 main landscape-scale parameters that may affect fish in seagrass. We tested their influence on the species richness per unit area and density of fish in 6 Zostera capricorni seagrass beds ranging in size from 2300 to $211200 \mathrm{~m}^{2}$, in the Pittwater estuary, NSW, Australia. The effect of edge interacted with bed size. The species richness was lower in edge than inner regions of the larger beds, but did not differ between regions in smaller beds, in which the species richness was similar to the inner regions of large beds. The density of fish (all species combined) varied with bed size in 1 of the 2 seasons sampled, but not with region. The densities of some individual species were lower in the larger beds compared to smaller beds (5 species), while others were greater ( 3 species), although for some species this was inconsistent between seasons. We then tested whether species richness and abundance were responding to patch area, perimeter, or perimeter:area ratio (P:A ratio) using artificial seagrass units (ASUs) of different shapes and sizes. All ASU designs had similar total abundances of fish species (per ASU), yet 1 design was smaller in area, so these smaller ASUs had greater species richness per unit area. The ASUs were smaller than the natural seagrass beds, and it seems that, although edge effects appeared in large natural seagrass beds, in smaller patches the total area rather than amount of edge influenced the species richness.
\end{abstract}

KEY WORDS: Seagrass $\cdot$ Fish $\cdot$ Fragmentation $\cdot$ Edge effects $\cdot$ Patch size $\cdot$ Artificial seagrass units

\section{INTRODUCTION}

Beds of the seagrass Zostera capricorni are a conspicuous component of estuarine landscapes along the temperate south-eastern coast of Australia (Bell \& Pollard 1989). They naturally tend to occur as elongated, continuous strips of vegetation. Like seagrass elsewhere they have been greatly affected by human activities (Duarte 2002), and have been reduced to smaller remnant patches surrounded by unvegetated sand (Short \& Wyllie-Echeverria 1996). Since Z. capricorni beds typically support a higher abundance and diversity of fish than adjacent unvegetated habitat (Bell \& Pollard 1989, Connolly 1994a, Jackson et al. 2002), fragmentation is assumed to be a threat to seagrass fishes. Fragmentation of seagrass involves a decrease in the area of seagrass cover, an increase in distance to the nearest habitat, changes in hydrodynamic functioning and an increase in the proportion of edge habitat (interface of sand and seagrass). This edge can be measured as an increase in the perimeter to area ratio ( $\mathrm{P}: \mathrm{A}$ ratio) of the seagrass bed. The P:A ratio of a seagrass bed can be obtained by simply dividing the perimeter of the bed by its area (Schumaker 1996).

Numerous researchers have considered the effects of seagrass fragmentation (with the concurrent decrease in patch size and increase in edge habitat) on seagrass fauna, although much of the work has been on infaunal or epifaunal invertebrates (e.g. Irlandi 1997, Eggleston et al. 1998, 1999, Irlandi et al. 1999, Bologna \& Heck 1999, Hovel \& Lipcius 2001). Early 
studies on fish examined rates of colonisation of artificial seagrass at different distances from natural beds (Sogard 1989) and the effects of patch area on fish species richness (McNeill \& Fairweather 1993). McNeill \& Fairweather (1993) found the species richness per unit area to be greater in numerous small patches than in 1 large patch of the same area. In experiments using artificial seagrass units (ASUs), however, they found that these results were not consistently upheld, although this difference could be attributed to the reduced power of the test $(<25 \%)$. Furthermore, the size difference between large $\left(14 \mathrm{~m}^{2}\right)$ and small $\left(7 \mathrm{~m}^{2}\right)$ ASUs was less than that in natural seagrass beds.

The greater abundance or density of organisms in small compared to large seagrass beds has been attributed to the influence of edge effects (McNeill \& Fairweather 1993, Eggleston et al. 1998, 1999, Irlandi et al. 1999, Bell et al. 2001). The edges of seagrass patches have been found to contain greater abundances of some fauna than the interiors (e.g. red drum fish Sciaenops ocellatus, Holt et al. 1983; bay scallop Argopecten irradians, Bologna \& Heck 1999; tulip mussel Modiolus americanus, Bologna \& Heck 2000; polychaete Kingbergonuphis simoni, Bell et al. 2001; mysids, BarberaCebrian et al. 2002; crustaceans, Tanner 2004), so researchers have considered the likelihood of sampling an edge to be the reason why more fauna is collected from small seagrass beds (McNeill \& Fairweather 1993, Bologna \& Heck 2000, Bell et al. 2001).

The potentially complex relationships between patch area, patch shape and P:A ratio have sometimes been oversimplified in seagrass landscape studies. Studies of patch area are often used to indicate potential edge effects, based on the assumption that the P:A ratio increases with decreasing patch area (Bell et al. 2001). Edge effects are best studied directly by sampling fauna at different distances into patches (e.g. Sanchez-Jerez et al. 1999, Bologna \& Heck 2002, Hovel \& Lipcius 2002, Hovel et al. 2002). Here, we attempt to tease apart any effects of patch area and edge by testing for edge effects in both small and large seagrass beds. We predict that the edge regions of seagrass beds will contain greater species richness than the inner regions, and that this difference will interact with bed size.

The ultimate test of the influence of patch area, perimeter and P:A ratio on fish is to manipulate these variables in a controlled experiment. This is only possible with the use of ASUs that have been shown to attract fauna similar to that found in natural seagrass (Bell et al. 1985, Sogard 1989). We designed ASUs so that it would be possible to separate the influences of patch area, perimeter and P:A ratio, and we predicted that the species richness (per unit area) and density of fish in artificial seagrass will be influenced by 1 of these factors alone.

\section{MATERIALS AND METHODS}

Survey of edge and inner regions of natural seagrass beds. This study was conducted in the Pittwater estuary, just north of Sydney, NSW, Australia $\left(33.6^{\circ} \mathrm{S}\right.$, $151.3^{\circ} \mathrm{E}$, see Bell et al. 1988). The Pittwater has a mean depth of $<5 \mathrm{~m}$, with dense urban development on the eastern and southern shores and extensive boating and recreational use.

Six monospecific beds of the dominant seagrass Zostera capricorni were selected based on their size, location in the lower reaches of the estuary and water depth (30 to $100 \mathrm{~cm}$ at mean low tide). Since fish assemblages vary with distance into the estuary (Bell et al. 1988), all beds in the current study were selected from the same region, within $4 \mathrm{~km}$ of the estuary mouth. The size of the seagrass beds ranged from 2290 to $211170 \mathrm{~m}^{2}$, and each bed was separated from the others by at least $200 \mathrm{~m}$ of bare sandy substratum, reducing the likelihood of faunal movement among beds during the sampling periods.

The edge of a seagrass bed was defined as the outer perimeter region, not including the sand. Peterson \& Turner (1994) found that the $3 \mathrm{~m}$ outer perimeter of saltmarshes had the greatest densities of fish. Studies of edge effects in seagrass have defined the edge as the $1 \mathrm{~m}$ outer perimeter; however, most of these considered either less mobile or smaller fauna than fish (bay scallop Argopecten irradians, Bologna \& Heck 1999; polychaete Kingbergonuphis simoni, Bell et al. 2001; mysids, Barbera-Cebrian et al. 2002; crustaceans, Tanner 2004). We defined the edge as the $4 \mathrm{~m}$ outer perimeter, based partly on the premise of obtaining enough animals in each sample to have a good chance of detecting patterns. The size of the edge region was also defined in practice by our preference to use a seine net ( $8 \mathrm{~m}$ long, but sampling $4 \mathrm{~m}$ when pulled). Seine nets are one of the more effective methods for capturing small fish in seagrass beds and sample a large area more rapidly than other methods (Connolly 1994b, Guest et al. 2003). The deeper seaward edges of the seagrass beds could not be sampled, because the water was $>100 \mathrm{~cm}$ deep at low tide. All other edges, including those parallel and perpendicular to the shore, were sampled. Within all seagrass beds, 2 regions were designated, edge ( 0 to $4 \mathrm{~m}$ from the outer perimeter) and inner ( 6 to $10 \mathrm{~m}$ from the outer perimeter). A $2 \mathrm{~m}$ buffer zone separated the 2 regions.

Fish were sampled in the austral autumn (March to May 2001) and spring (September to November 2001). Fish were collected with an $8 \times 2 \mathrm{~m}$ seine net $(1 \mathrm{~mm}$ mesh) that was pulled for $10 \mathrm{~m}$, sampling an area approximating $35 \mathrm{~m}^{2}$. We sampled from low to midtide (water depth: 40 to $80 \mathrm{~cm}$ ), because previous research demonstrated this to be the most effective 
tidal state for the seine net and maximised the number of fish species collected (Jelbart 2004). Each region of every bed was sampled 3 times per season, at randomly selected positions, with the proviso that no area was sampled twice. Samples were taken after nightfall, because this is the time that gives the greatest fish species richness (Jelbart 2004). The order of sampling regions and beds was randomised.

Two-factor analyses of covariance (ANCOVA) were used to compare the number of fish species per net (species richness), and densities of fish individuals and the most numerous single species between seasons (orthogonal, fixed) and the regions of beds (orthogonal, fixed), using bed size as the covariate. All data were tested for heteroscedasticity (Cochran's test) and transformed $\left(\log _{10}\right)$ when necessary. A Tukey test was used to detect post hoc differences among means. When a significant interaction term involving bed size was detected in the ANCOVA, this meant that the relationship between the dependent variable and bed size differed among levels of the factor. It is difficult to proceed with conventional testing in this situation, but we were able to continue to analyse the data by adjusting the dependent variable using the slopes of the regression relationships with bed size, and then performing a 3-factor analysis of variance (ANOVA) on these data adjusted for the influence of bed size, with the factors season (orthogonal, fixed), regions of beds (orthogonal, fixed) and bed (nested in seasons, random).

Experimentation using artificial seagrass patches. Artificial seagrass units were designed to mimic Zostera capricorni in the Pittwater estuary. Plastic garden mesh $(5 \times 5 \mathrm{~cm}$ mesh size) was used for the base of the ASUs. To produce a fringe of seagrass blades, black polyethylene plastic was cut into a seagrass comb or fringe that mimicked the natural size and shape of $Z$. capricorni blades (5 mm wide and $200 \mathrm{~mm}$ long). Z. capricorni is dark olive in colour and appears dark brown when submerged, so black was considered a suitable surrogate in colour. The blade density of the ASUs was 525 blades $\mathrm{m}^{-2}$, which was within the density range of natural seagrass in the Pittwater estuary (Jelbart 2004). The arrangement of blades was haphazard to ensure the ASUs were not more uniform in cover than the natural seagrass.

Three ASU designs were used: (1) a large square with a large area and small perimeter, (2) a large rectangle with a large area and large perimeter and (3) a small rectangle with a small area and small perimeter (Fig. 1). These designs separate the influences of patch area, perimeter and P:A ratio on the species richness and densities of fish. If area is the determining factor, then the large squares will equal the larger rectangles, but differ from the small rectangles. If perimeter is the

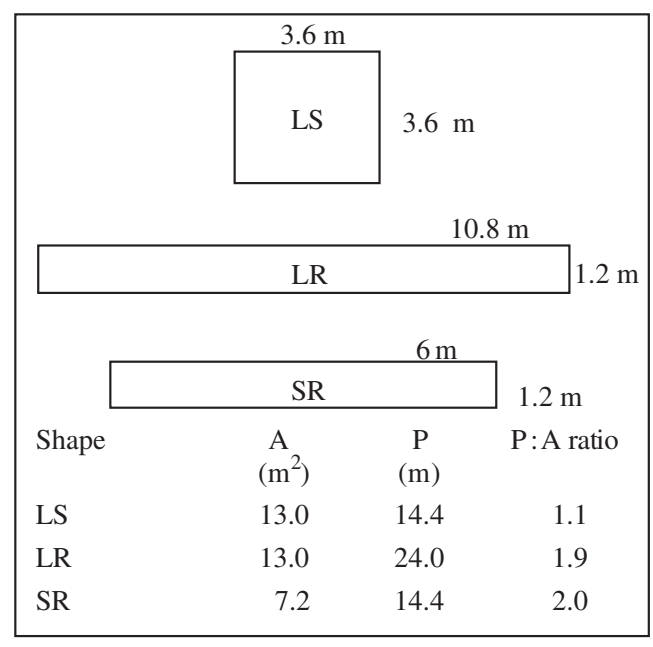

Fig. 1. Description of the 3 artificial seagrass unit designs (LS: large square; LR: large rectangle; SR: small rectangle; A: area; P: perimeter). To test which feature influenced abundance of fauna, predictions were as follows: if area then LS = $\mathrm{LR} \neq \mathrm{SR}$; if perimeter then $\mathrm{LS}=\mathrm{SR} \neq \mathrm{LR}$; if perimeter:area ratio then $\mathrm{LS} \neq \mathrm{LR}=\mathrm{SR}$

determining factor, then the large squares will equal the small rectangles, but differ from the large rectangles. Finally, if the P:A ratio is the determining factor, then the large rectangles will equal the small rectangles, but differ from the large squares. There were 2 replicates of each patch design at 2 locations (a total of 4 replicates for each design and 12 ASUs in all).

The ASUs were placed on bare sand substratum at 2 locations in the Pittwater estuary after the spring survey period described above. The order and spatial orientation of the ASUs was random. Each ASU was $>15 \mathrm{~m}$ from other ASUs, and all were approximately $20 \mathrm{~m}$ from natural Zostera capricorni beds and in similar water depths (30 to $80 \mathrm{~cm}$ at low tide). Sogard (1989) found that fish colonised ASUs in proportion to their distance from natural seagrass beds, but by placing the units equidistant $(20 \mathrm{~m})$ from natural seagrass beds we controlled for any influence of nearby habitats. Sand accreting on ASUs was cleared manually from all units 3 wk after deployment, with standardised effort for each ASU.

The fish fauna was sampled from the ASUs after $39 \mathrm{~d}$. In previous studies, the time of sampling of fish in artificial seagrass units varied from: within a few days (Virnstein \& Curran 1986), after 12 d (Levin et al. 1997), after 6 wk (Bell et al. 1985, McNeill \& Fairweather 1993) and every week for 5 mo (Sogard 1989). Our 39 d period was considered long enough to represent several settlement and post-settlement events (Sogard 1989).

Sampling was done at the same time of day and water depth as for the natural beds. In the afternoon 
preceding sampling, posts were deployed around the edge of the units and a drop net constructed out of $1 \mathrm{~mm}$ mesh (1.2 m high and weighted with lead) was suspended above the water line. At the time of sam-

Table 1. Total abundances of fish in edge and inner regions of natural seagrass beds, separated arbitrarily into categories of 3 smallest and 3 largest beds (autumn and spring combined). Each value is number of fish sampled from a total of $210 \mathrm{~m}^{2}$

\begin{tabular}{|c|c|c|c|c|c|}
\hline \multirow{3}{*}{$\begin{array}{l}\text { Family } \\
\text { Apogonidae }\end{array}$} & \multirow{2}{*}{$\begin{array}{l}\text { Species } \\
\text { Apogon cookii }\end{array}$} & \multicolumn{2}{|c|}{$\begin{array}{l}\text { Small beds } \\
\text { Edge Inner }\end{array}$} & \multicolumn{2}{|c|}{$\begin{array}{l}\text { Large beds } \\
\text { Edge Inne }\end{array}$} \\
\hline & & 4 & 4 & 0 & 0 \\
\hline & Vincentia novaehollandiae & 0 & 4 & 0 & 0 \\
\hline Atherinidae & Atherinomorus ogilbyi & 33 & 26 & 102 & 34 \\
\hline Blenniidae & Petroscirtes lupus & 1 & 0 & 0 & 0 \\
\hline Chandidae & Ambassis jacksoniensis & 0 & 0 & 33 & 115 \\
\hline \multirow[t]{3}{*}{ Clinidae } & Cristiceps aurantiacus & 0 & 0 & 3 & 2 \\
\hline & Heteroclinus fasciatus & 0 & 0 & 1 & 4 \\
\hline & Heteroclinus whiteleggi & 1 & 0 & 1 & 0 \\
\hline Clupeidae & Hyperlophus translucidus & 5 & 1 & 1 & 1 \\
\hline Diodontidae & Dicotylichthys punctulatus & 0 & 1 & 0 & 0 \\
\hline Gerreidae & Gerres subfasciatus & 0 & 0 & 34 & 87 \\
\hline Girellidae & Girella tricuspidata & 0 & 0 & 5 & 4 \\
\hline \multirow[t]{4}{*}{ Gobiidae } & Arenigobius frenatus & 292 & 273 & 742 & 522 \\
\hline & Bathygobius kreffti & 121 & 103 & 72 & 58 \\
\hline & Cristatogobius gobioides & 0 & 0 & 1 & 1 \\
\hline & Redigobius macrostoma & 1 & 0 & 8 & 10 \\
\hline Labridae & Achoerodus viridis & 0 & 0 & 0 & 1 \\
\hline \multirow[t]{7}{*}{ Monacanthidae } & Acanthaluteres spilomelanurus & 1 & 5 & 1 & 4 \\
\hline & Cantherhinus pardalis & 3 & 1 & 0 & 2 \\
\hline & Eubalichthys mosaicus & 3 & 6 & 0 & 0 \\
\hline & Meuschenia trachylepis & 1 & 0 & 0 & 0 \\
\hline & Meuschenia venusta & 2 & 0 & 0 & 0 \\
\hline & Monacanthus chinensis & 3 & 3 & 1 & 2 \\
\hline & Scobinichthys granulatus & 1 & 2 & 1 & 1 \\
\hline \multirow[t]{4}{*}{ Mullidae } & Parupeneus signatus & 1 & 1 & 1 & 0 \\
\hline & Upeneichthys lineatus & 3 & 0 & 0 & 0 \\
\hline & Upeneus sp. & 16 & 16 & 4 & 0 \\
\hline & Upeneus tragula & 22 & 28 & 3 & 5 \\
\hline Odacidae & Neoodax balteatus & 0 & 0 & 0 & 1 \\
\hline Ostraciidae & Lactoria cornuta & 0 & 0 & 0 & 0 \\
\hline Paralichthyidae & Pseudorhombus jenynsii & 0 & 1 & 0 & 0 \\
\hline \multirow[t]{2}{*}{ Plotosidae } & Cnidoglanis macrocephala & 0 & 0 & 1 & 1 \\
\hline & Plotosus lineatus & 0 & 0 & 0 & 1 \\
\hline Scorpaenidae & Centropogon australis & 159 & 120 & 136 & 118 \\
\hline Serranidae & Epinephelus daemelii & 0 & 0 & 1 & 0 \\
\hline Siganidae & Siganus nebulosus & 1 & 1 & 0 & 1 \\
\hline \multirow[t]{2}{*}{ Sillaginidae } & Sillago ciliata & 1 & 0 & 0 & 0 \\
\hline & Sillago maculata & 1 & 0 & 1 & 2 \\
\hline Sparidae & Rhabdosargus sarba & 12 & 8 & 36 & 40 \\
\hline Sphyraenidae & Sphyraena obtusata & 2 & 1 & 0 & 1 \\
\hline \multirow[t]{6}{*}{ Syngnathidae } & Filicampus tigris & 2 & 3 & 0 & 0 \\
\hline & Hippocampus whitei & 1 & 0 & 0 & 0 \\
\hline & Stigmatopora argus & 0 & 0 & 3 & 0 \\
\hline & Stigmatopora nigra & 24 & 17 & 7 & 6 \\
\hline & Urocampus carinirostris & 53 & 23 & 34 & 34 \\
\hline & Vanacampus margaritifer & 0 & 0 & 0 & 1 \\
\hline Tetraodontidae & Tetractenos hamiltoni & 0 & 0 & 1 & 1 \\
\hline Terapontidae & Pelates sexlineatus & 28 & 25 & 127 & 227 \\
\hline
\end{tabular}

pling, the net was dropped rapidly and fastened into the sand with pegs. A scoop net $(3.6 \mathrm{~m}$ wide for the square and $1.2 \mathrm{~m}$ wide for the rectangular units) was dragged over the ASUs 4 times. In the pilot stage of this project 4 drags were found to be enough to collect all fish (no more fish sampled after 3 drags of net).

Differences among patch designs were tested using a 2-factor fixed, orthogonal ANOVA: sampling location with 2 levels and ASU design with 3 levels ( $\mathrm{n}=2$ for each combination of factors). This model was used to compare among ASUs the species richness per ASU and per unit area, and the total number and density of fish and selected single species. Species richness and the density of fish individuals required transformation $(\ln [x+1])$.

Over the period of the experiment, a variable amount of algae grew on the surface of all ASUs. Bologna \& Heck (2000) found that the density of bivalves was significantly greater in ASUs that were fouled by epiphytes than units without algae. To check that the amount of algae on the ASUs did not confound the experiment, the algae were collected from the ASUs and weighed.

A linear regression was used to test for a relationship between the total number $\left(\right.$ net $^{-1}$ ) of fish species, fish individuals and single species and the amount of algae collected from each ASU. A 2-factor fixed, orthogonal ANOVA (as above) was used to test if the different ASU designs accumulated different amounts of algae.

\section{RESULTS}

\section{Survey of edge and inner regions of natural seagrass beds}

A total of 48 fish species was collected from the natural seagrass beds (Table 1). The ANCOVA on the species richness $\left(\right.$ net $\left.^{-1}\right)$ demonstrated that, overall, $45 \%$ of the variability was explained by the variables season, bed size and region. The ANCOVA detected a significant effect of bed size $\left(F_{1,1}=6.49, \mathrm{p}=0.013\right)$ and 


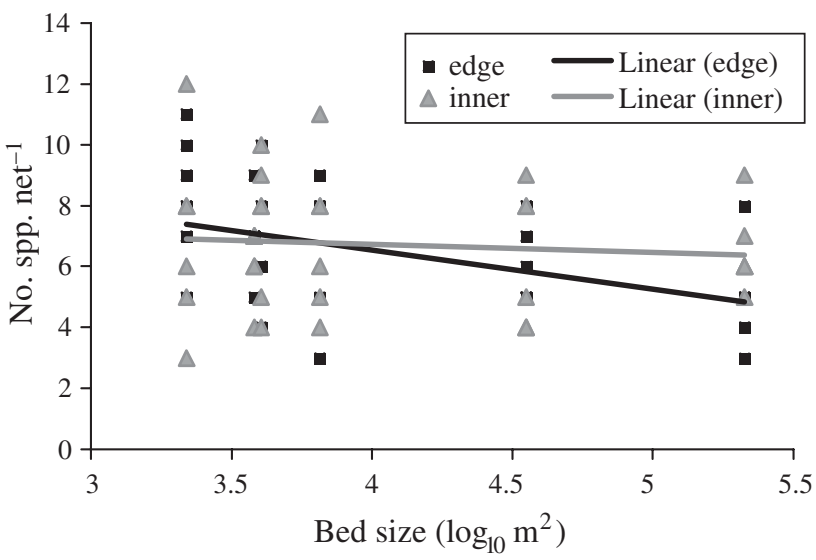

Fig. 2. Relationship between species richness and bed size $\left(\log _{10} \mathrm{~m}^{2}\right)$ in edge and inner regions of natural seagrass beds

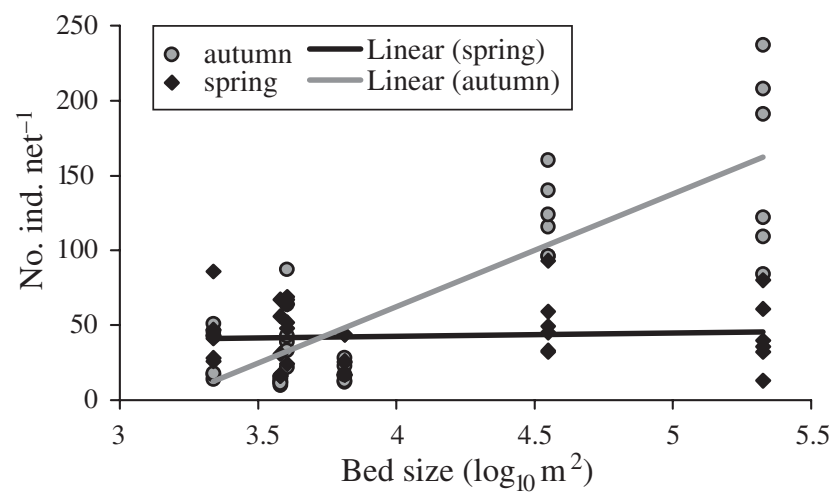

Fig. 3. Relationship between density of fish individuals and bed size $\left(\log _{10} \mathrm{~m}^{2}\right)$ in autumn and spring in natural seagrass beds

season of sampling $\left(F_{1,1}=6.03, \mathrm{p}=0.017\right)$; however, there was a significant interaction with region of bed $\left(\right.$ size $\times$ region; $\left.F_{1,1}=4.385, \mathrm{p}=0.040\right)$. There was no interaction with season (size $\times$ season; $F_{1,1}=1.96, \mathrm{p}=$ 0.167 ). Given that the slopes of the regression relationships were different between the edge and inner regions (Fig. 2), we adjusted the species richness for the influence of bed size, separately for the 2 regions, before using the 3-factor ANOVA. This analysis found a strong seasonal effect $\left(F_{1,10}=46.32, p<0.001\right)$ (Fig. 3), no effect of region $\left(F_{1,10}=0.38, \mathrm{p}=0.551\right)$ or $\operatorname{bed}_{\text {season }}\left(F_{10,48}=0.88, \mathrm{p}=0.555\right)$, and no significant interactions. A post hoc test revealed that beds had greater species richness $\left(\right.$ net $^{-1}$ ) in autumn than spring (means of 8 and 7 species net ${ }^{-1}$ in autumn and spring, respectively). Although the mean species richness did not differ between edge and inner regions of seagrass beds, the relationship between bed size and species richness was different. There was no relationship between bed size and species richness in the inner regions $\left(R^{2}=0.01, p=0.804\right)$; however, in the edge regions a negative relationship was detected $\left(\mathrm{R}^{2}=\right.$ 0.17, $\mathrm{p}=0.012$ ). Across both seasons, there was lower species richness in the edge than inner regions in larger but not in smaller beds (Fig. 2).

The ANCOVA on the densities of all fish demonstrated that, overall, $49 \%$ of the variability was explained by the variables season, bed size and region. The ANCOVA detected a significant effect of bed size $\left(F_{1,1}=32.91, \mathrm{p}<0.001\right)$ and season of sampling $\left(F_{1,1}=\right.$ 25.93, p $<0.001)$; however, there was a significant interaction $\left(\right.$ size $\times$ season; $\left.F_{1,1}=27.60, \mathrm{p}<0.001\right)$. There was no interaction with region (size $\times$ region; $F_{1,1}=0.006, \mathrm{p}=0.939$ ). Given that the slopes of the regression relationships were different between seasons (Fig. 3), we adjusted the densities of fish for the effects of bed size, separately for the 2 seasons, and then ran a 3-factor ANOVA. This analysis found no effect of season $\left(F_{1,10}=0.08, \mathrm{p}=0.783\right)$ or region $\left(F_{1,10}=\right.$ $0.42, \mathrm{p}=0.532)$, a strong effect of bed(season) $\left(F_{10,48}=\right.$ $6.44, \mathrm{p}<0.001$ ) and no significant interactions. For both seasons there was great variability in the densities among beds that was not correlated with bed size. However, in autumn alone, densities were positively correlated with bed size $\left(R^{2}=0.61, p<0.001\right)$, but this correlation was not detected in spring $\left(\mathrm{R}^{2}=0.01, \mathrm{p}=\right.$ 0.704) (Fig. 3).

Six of the 12 common taxa were influenced by bed size. Bathygobius kreffti $\left(F_{1,1}=14.23, \mathrm{p}<0.001\right)$, Urocampus carinirostris $\left(F_{1,1}=7.18, \mathrm{p}=0.009\right)$, Upeneus sp. $\left(F_{1,1}=23.76, \mathrm{p}<0.001\right)$ and Monacanthidae $\left(F_{1,1}=16.64, \mathrm{p}<0.001\right)$ declined in density (number net ${ }^{-1}$ ) as bed size increased (Fig. 4A). $U$. carinirostris was also more abundant during spring than autumn $\left(F_{1,1}=6.18, \mathrm{p}=0.015\right)$ and was the only species influenced by region. There were greater densities of $U$. carinirostris in the edge than inner regions of beds $\left(F_{1,1}=4.66, \mathrm{p}=0.035\right)$. Only 2 species increased in densities as bed size increased: Ambassis jacksoniensis $\left(F_{1,1}=21.18, \mathrm{p}<0.001\right)$ and Rhabdosargus sarba $\left(F_{1,1}=7.499, \mathrm{p}=0.008\right)$ (Fig. $4 \mathrm{~B})$. $R$. sarba was also found in greater densities during spring than autumn $\left(F_{1,1}=8.72, \mathrm{p}=0.004\right)$. Three species had significant interaction terms (size $\times$ season) that reflected a different relationship with bed size during the spring and autumn. The densities of Arenigobius frenatus and Atherinomorus ogilbyi were positively correlated with bed size in autumn $\left(F_{1,1}=14.66, \mathrm{p}<0.001\right.$ and $F_{1,1}=36.82, \mathrm{p}<0.001$, respectively) (Fig. 4C). Stigmatopora nigra was negatively correlated with bed size in spring $\left(F_{1,1}=11.78\right.$, $\mathrm{p}=0.001$ ) (Fig. 4D). Only 2 of the 12 taxa analysed, Centropogon australis and Pelates sexlineatus, did not show significant differences with any of the variables (season, bed size and region). 


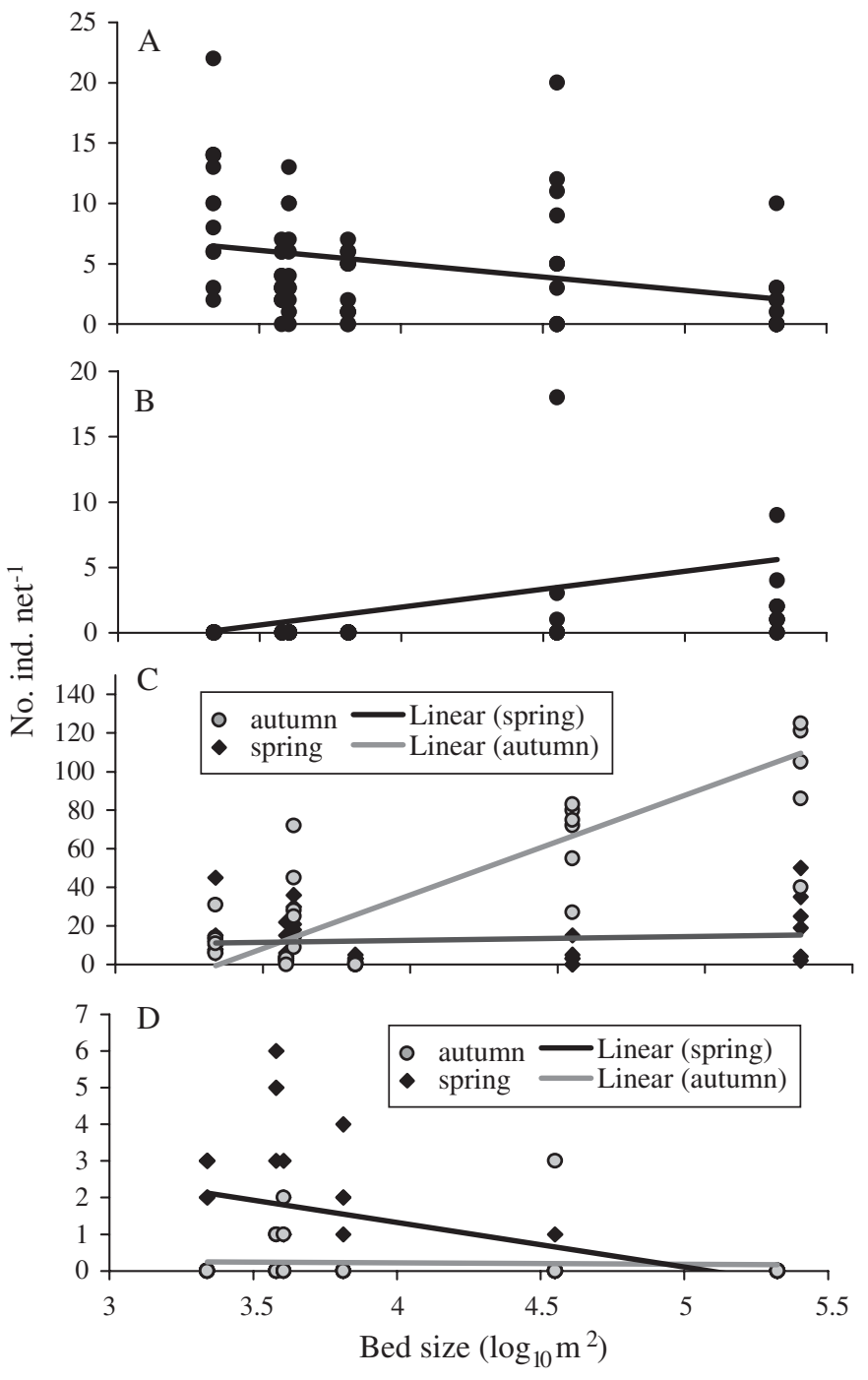

Fig. 4. Relationships between single-species density and bed size $\left(\log _{10} \mathrm{~m}^{2}\right)$, showing examples of the 4 patterns: (A) Bathygobius kreffti, negative; (B) Ambassis jacksoniensis, positive; (C) Arenigobius frenatus, positive in 1 season only; and

(D) Stigmatopora nigra, negative in 1 season only

\section{Experimentation using ASUs}

A total of 19 species of fish (401 individuals) was captured in ASUs (Table 2). The most abundant species were the estuary catfish Cnidoglanis macrocephalus (115 individuals), the eastern-striped trumpeter Pelates sexlineatus (70), the half-bridled goby Arenigobius frenatus (66) and the bar-tailed goatfish Upeneus tragula (61). Five species of leatherjackets (Monacanthidae) were also collected (39 individuals).

There were no significant differences in the total species richness and density of all fish (per ASU) collected from the 3 designs (Fig. 5, Table 3). There were, however, differences in the species richness per unit area among designs (Fig. 5, Table 3). The species rich- ness per unit area was highest in small rectangular ASUs, lowest in square ASUs and intermediate in large rectangular ASUs. This suggests that patch area was the strongest influence on species richness. The somewhat higher species richness per unit area in large rectangular ASUs than square ASUs means that there might also be a secondary effect of P:A ratio or perimeter. However, we rank this as a secondary influence since species richness per unit area in small rectangular ASUs was greater still. No significant differences were found among patch designs for the variables density of all fish and density of individual species (the 8 most common species were tested, comprising $92 \%$ of the total number of fish collected).
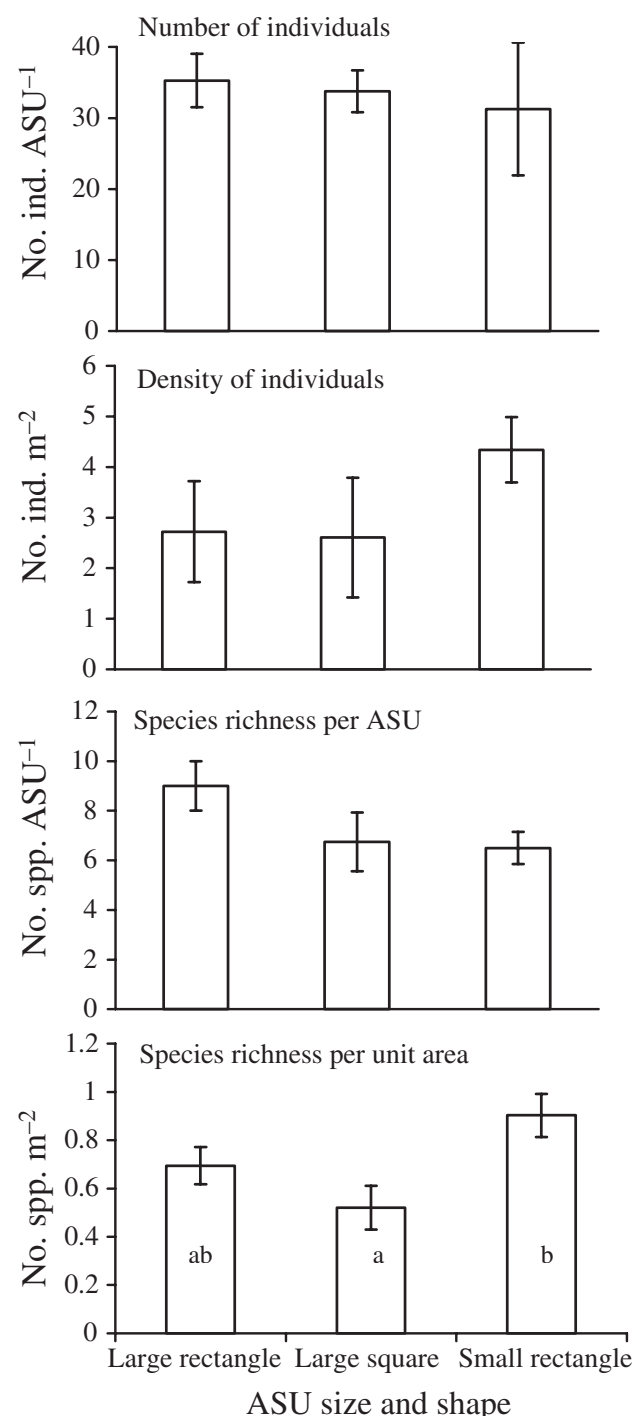

Fig. 5. Total numbers and densities of fish individuals and species richness (mean $\pm \mathrm{SE}$ ) collected from the 3 artificial seagrass unit (ASU) designs $(n=4)$. Letters a \& b denote groups that are statistically different from one another; no letters shown when ANOVA was not significant 
Table 2. Fish collected from different artificial seagrass unit designs. In large squares and rectangles, total area sampled was $52 \mathrm{~m}^{2}$, and in small rectangles it was $29 \mathrm{~m}^{2}$

\begin{tabular}{|llccc|}
\hline Family & Species & $\begin{array}{c}\text { Large } \\
\text { squares }\end{array}$ & $\begin{array}{c}\text { Large } \\
\text { rectangles }\end{array}$ & $\begin{array}{c}\text { Small } \\
\text { rectangles }\end{array}$ \\
\hline Atherinidae & Atherinomorus ogilbyi & 1 & 4 & 0 \\
Batrachoididae & Batrachomoeus dubius & 2 & 6 & 0 \\
Gobiidae & Arenigobius frenatus & 26 & 25 & 12 \\
& Bathygobius kreffti & 0 & 2 & 6 \\
Monacanthidae & Acanthalutere spilomelanurus & 2 & 1 & 0 \\
& Cantherhinus pardalis & 3 & 2 & 2 \\
& Eubalichthys mosaicus & 4 & 5 & 11 \\
Mullidae & Scobinichthys granulatus & 3 & 4 & 0 \\
& Upeneus sp. & 4 & 10 & 1 \\
Scorpaenidae & Upeneus tragula & 29 & 20 & 12 \\
Plotosidae & Centropogon australis & 0 & 2 & 1 \\
Syngnathidae & Cnidoglanis macrocephalus & 41 & 22 & 52 \\
Terapontidae & Pecampus carinirostris & 0 & 6 & 2 \\
Other singleton & & 18 & 28 & 24 \\
species & & 2 & 4 & 2 \\
Total fish & & 135 & 141 & 125 \\
\hline
\end{tabular}

Table 3. ANOVA results comparing species richness and densities of fish from artificial seagrass units (ASU). The only significant value is in bold

\begin{tabular}{|c|c|c|c|}
\hline Source of variation & $\mathrm{df}$ & $F(\mathrm{p})$ & $F(\mathrm{p})$ \\
\hline & & No. fish (ind. $\mathbf{A S U}^{-1}$ ) & Density of fish (ind. $\mathrm{m}^{-2}$ ) \\
\hline Location & 1 & $0.0(0.953)$ & $0.0(0.958)$ \\
\hline Patch design & 2 & $0.4(0.708)$ & $1.5(0.288)$ \\
\hline Location $\times$ patch & 2 & $1.0(0.419)$ & $1.0(0.421)$ \\
\hline & & Species richness $\mathrm{ASU}^{-1}$ & Species richness $\mathbf{m}^{-2}$ \\
\hline Location & 1 & $0.2(0.677)$ & $1.0(0.357)$ \\
\hline Patch design & 2 & $1.8(0.225)$ & $5.2(0.049)$ \\
\hline Location $\times$ patch & 2 & $1.2(0.361)$ & $1.3(0.341)$ \\
\hline
\end{tabular}

the seagrass bed was also considered in the analysis. Larger beds had lower species richness per unit area in the edge than in inner regions and the edge regions of smaller beds. In small seagrass beds $\left(<6500 \mathrm{~m}^{2}\right)$ the species richness was similar between edge and inner regions. A relatively large proportion of the variability in species richness $(45 \%)$ could be explained by the combination of bed region, bed area and season. A finding such as this of an interaction between edge effects and bed area potentially explains the lack of consistency in the findings of edge effects across the literature. Studies that have measured edge effects directly by sampling at different distances into beds have had conflicting findings. Some studies have found fauna to be less dense at the edge than in inner regions of seagrass beds (Sanchez-Jerez et al. 1999, Hovel \& Lipcius 2002, Hovel et al. 2002). In contrast, other studies have found that the edges of seagrass beds contain greater densities of some fauna (Bologna \& Heck 1999, 2002, BarberaCebrian et al. 2002, Tanner 2004). These studies cover a range of marine organisms with greatly varying dispersal mechanisms, so generalisations across all studies cannot necessarily be expected. Eggleston et al. (1998, 1999) found that an organism's response to patch size was species spe-

Neither the total biomass of algae collected from ASUs nor the density of algae (biomass per unit area) differed significantly among the patch designs (factors design and site and the interaction between them were all non-significant). Three species were correlated with the amount of epiphytic algae collected from each ASU: Pelates sexlineatus $\left(\mathrm{R}^{2}=0.35, \mathrm{p}<0.05\right.$, positive correlation), Cnidoglanis macrocephalus $\left(\mathrm{R}^{2}=0.36, \mathrm{p}<\right.$ 0.05 , positive) and Upeneus sp. $\left(\mathrm{R}^{2}=0.42\right.$, $\mathrm{p}<0.05$, negative).

\section{DISCUSSION}

\section{Interaction of edge effects and bed size in natural seagrass}

Our study revealed that for small fish in seagrass beds edge effects were only detected when the size of cific and dependent on body size and habitat type. Furthermore, some studies have shown that patterns vary through time. For example, Hovel et al. (2002) found that the edge-inner comparison explained a significant, albeit small (16\%), amount of the variability in pinfish Lagodon rhomboides densities, but only in 1 season.

The greater effect of edges in larger than in smaller beds is surprising given that edge effects have been assumed to be more important in smaller patches (McNeill \& Fairweather 1993), but an understanding of the faunal dynamics within seagrass beds can shed light on this finding.

McNeill \& Fairweather (1993) found that numerous small natural seagrass beds had greater total species richness than 1 large bed of the same total area. They attributed this to the greater likelihood of sampling an edge in a small bed compared to a large bed, under the assumption that edges contain more species. However, 
our study suggests that there are no edge effects on species richness in small beds. We attribute the detection of edge effects in larger beds to the higher rates of predation on the edges of large beds compared to smaller beds and inner regions of all bed sizes. Predation is the most commonly cited mechanism underlying patterns in fish abundances with different-sized beds (Irlandi et al. 1999, Hovel \& Lipcius 2001, Laurel et al. 2003). It has been proposed that smaller seagrass beds may be too small to support large abundances of top predators (Eggleston et al. 1998, 1999, Hovel \& Lipcius 2001). Hovel \& Lipcius (2001) found that small seagrass beds contained more juvenile blue crabs Callinectes sapidus because the beds were too small to support its main predator, conspecific adult blue crabs. Predation rates are also greater at patch edges (Hovel \& Lipcius 2002), and in patchy rather than homogeneous meadows (Hovel \& Fonseca 2005). Predation rates have also been shown to be higher on seagrass patch edges for other faunal groups (Bologna \& Heck 1999). Given the evidence for the influence of predation on individual species (Hindell et al. 2001), predation is likely to be an important factor underlying the lower species richness we found in the edges of large beds. It is possible that a similar edge effect exists in smaller beds, but we failed to detect it. If, for example, an edge effect exists in smaller beds, but operates on a smaller scale, then the designated $4 \mathrm{~m}$ edge region might have been too wide in smaller beds, while proving successful in larger beds.

In the single-species analysis we found only 1 species to be influenced by edge effects. The hairy pipefish Urocampus carinirostris was more numerous in the edge than in inner regions (regardless of season or bed area). This species is a cryptic, ambush predator of small crustaceans (Howard \& Koehn 1985). Food availability has previously been shown to affect fish distributions (Connolly 1994c,d). U. carinirostris may be more abundant on the edges of seagrass because it has greater access there to incoming plankton.

The density of all fish did not demonstrate a similar pattern to that found for species richness. During autumn, exactly the opposite pattern occurred, with greater densities of fish in larger than in smaller beds, although this can mostly be attributed to the goby Arenigobius frenatus, which was very abundant in larger beds, but only in autumn.

\section{Patterns in ASUs}

As shown previously (Bell et al. 1985, Sogard 1989), the ASUs were successful mimics of natural seagrass. The lower overall diversity in ASUs was a result of the greater area sampled in natural beds (about 6 times greater). Just 1 species caught on the ASUs was not caught in the natural beds (Batrachomoeus dubius), but this species has been collected from Pittwater seagrass previously (Jelbart 2004).

Whereas in natural seagrass beds the relationship between area and perimeter is complicated by the different shapes of beds, we were able to manipulate the shape of ASUs to test between the influences of area, perimeter and P:A ratio. The ASU experiment showed that the species richness per unit area was greater in small ASUs. This is the same relationship shown for natural beds, and is remarkable given that the ASUs are at the smallest end of the scale of natural seagrass beds in Pittwater. We could not measure edge effects directly in ASUs, but should have detected any major edge effect as an influence in the $\mathrm{P}: \mathrm{A}$ ratio. There was a hint of $\mathrm{P}: \mathrm{A}$ ratio influence, but this was clearly secondary to the influence of area alone. Care must be taken in interpreting non-significant results such as these. Although we know the statistical power was enough to detect an overall difference among means, the power of the post hoc pair-wise Student-Newman-Keuls test is an issue here. It is also worth noting that, in natural seagrass, edge effects were only detected in larger beds, and so it would be worthwhile experimenting with much larger ASUs. We attempted to make the ASUs as large as possible given resource constraints, but, while they were larger than in many previous studies, there is scope for even larger ASUs to be employed (e.g. Laurel et al. 2003).

\section{Explanatory model}

We postulate that the higher species richness (per unit area) in smaller beds, natural or artificial, results from an isolation effect first described by Sogard (1989). Sogard found that ASUs of the same size, but placed at different distances from large natural beds, had different densities of fish species. ASUs further from natural seagrass and, therefore, surrounded by a greater area of unvegetated sand had higher species densities (Sogard 1989). Sogard pointed out that ASUs further from natural beds were also closer to oceanic water, a factor known to affect fish assemblages in other places (Connolly 1994a). Nevertheless, Sogard's results might be explained by the same mechanism we are postulating. If a seagrass bed contains fish species that are attracted to it from adjacent unvegetated sand habitat (Jackson et al. 2001), then an isolated bed will potentially contain species attracted from the surrounding area. If, as in Pittwater, all of the beds (even the large ones) are small relative to the vast area of surrounding unvegetated 
habitat, then the area from which fish are attracted might be many times larger than the area of the beds themselves. If the size of beds is trivial relative to the area from which fish are attracted, then all beds, regardless of size, will attract fish from about the same area. The total number of species (species richness) will therefore show no pattern with bed area. The species richness per unit area, however, will be greater in smaller beds.

\section{Correlation of some fish species with epiphytic algae}

The amount of epiphytic algae collected from the ASUs was correlated with the abundance of 3 species of fish and may reflect their habitat or prey selection. The abundance of juvenile Pelates sexlineatus was positively correlated with the amount of epiphytic algae, and may be explained by their reported behaviour of congregating around floating algae (Kuiter 2000). The juvenile catfish Cnidoglanis macrocephala was also positively correlated with the amount of epiphytic algae. In contrast, Upeneus sp. had a negative correlation with the amount of epiphytic algae. This species is known to hunt for invertebrate prey in unvegetated sand (Kuiter 2000), and perhaps avoids areas with dense cover of macroalgae. It has been found that the abundance of mobile fauna can increase with the accumulation of macroalgae on seagrass, possibly due to the short-term increase in structural complexity (Holmquist 1997). However, more work is required to clarify why individual species respond to the accumulation of epiphytic algae on seagrass.

\section{Conclusions}

The species richness per unit area in smaller natural seagrass beds was consistently greater than that in larger beds, and this difference can be attributed to the lower numbers in edge regions of the larger beds. Similarly, area had the strongest influence on species richness per unit area in ASU patches. The interaction between edge effects and bed area means that future work in these seagrass meadows should focus on processes that operate differently across the range of bed sizes. This will also be worth considering in other places where studies of edge effects have so far found no patterns.

Acknowledgements. We are grateful for support from the School of Natural Sciences at the University of Western Sydney, and especially to M. Schnell and S. Claus, for assistance. This research was conducted with institutional, national and international guidelines concerning the use of animals in research.

\section{LITERATURE CITED}

Barbera-Cebrian C, Sanchez-Jerez P, Ramos-Espla AA (2002) Fragmented seagrass habitats on the Mediterranean coast, and distribution and abundance of mysid assemblages. Mar Biol 141:405-413

Bell JD, Pollard DA (1989) Ecology of fish assemblages and fisheries associated with seagrasses. In: Larkum AWD, McComb AJ, Shepherd SA (eds) Biology of seagrasses. Elsevier, Amsterdam, p 565-609

Bell JD, Steffe AS, Westoby M (1985) Artificial seagrass: How useful is it for field experiments on fish and macroinvertebrates? J Exp Mar Biol Ecol 90:171-177

Bell JD, Steffe AS, Westoby M (1988) Location of seagrass beds in estuaries: effects on associated fish and decapods. J Exp Mar Biol Ecol 122:127-146

Bell SS, Brooks RA, Robbins BD, Fonseca MS, Hall MO (2001) Faunal response to fragmentation in seagrass habitats: implications for seagrass conservation. Biol Conserv 100: 115-123

Bologna PAX, Heck KL (1999) Differential predation and growth rates of bay scallops within a seagrass habitat. J Exp Mar Biol Ecol 239: 299-314

Bologna PAX, Heck KL (2000) Impacts of seagrass habitat architecture on bivalve settlement. Estuaries 23:449-457

Bologna PAX, Heck KL (2002) Impact of habitat edges on density and secondary production of seagrass-associated fauna. Estuaries 25:1033-1044

Connolly RM (1994a) A comparison of fish assemblages from seagrass and unvegetated areas of a southern Australian estuary. Aust J Mar Freshw Res 45:1033-1044

Connolly RM (1994b) Comparison of fish catches from a buoyant pop net and a beach seine net in a shallow seagrass habitat. Mar Ecol Prog Ser 109:305-309

Connolly RM (1994c) Removal of seagrass canopy: effects on small fish and their prey. J Exp Mar Biol Ecol 184:99-110

Connolly RM (1994d) The role of seagrass as preferred habitat for juvenile Sillaginodes punctata (Sillaginidae, Pisces): Habitat selection or feeding? J Exp Mar Biol Ecol 180:39-47

Eggleston DB, Etherington LL, Elis WE (1998) Organism response to habitat patchiness: species and habitatdependent recruitment of decapod crustaceans. J Exp Mar Biol Ecol 223:111-132

Eggleston DB, Elis WE, Etherington LL, Dahlgren CP, Posey MH (1999) Organism responses to habitat fragmentation and diversity: habitat colonization by estuarine macrofauna. J Exp Mar Biol Ecol 236:107-132

Duarte CM (2002) The future of seagrass meadows. Environ Conserv 29:192-206

Guest M, Connolly RM, Loneragan NR (2003) Seine nets and beam trawls compared in the day and night for sampling fish and crustaceans in shallow seagrass habitat. Fish Res 64:185-196

Hindell JS, Jenkins GP, Keough MJ (2001) Spatial and temporal variability in the effects of fish predation on macrofauna in relation to habitat complexity and cage effects. Mar Ecol Prog Ser 224:231-250

Holmquist JG (1997) Disturbance and gap formation in a marine benthic mosaic: influence of shifting macroalgae patches on seagrass structure and mobile invertebrates. Mar Ecol Prog Ser 158:121-130

Holt SA, Kitting CL, Arnold CR (1983) Distribution of young red drums among different seagrass meadows. Trans Am Fish Soc 112:267-271

Hovel KA, Fonseca MS (2005) Influence of seagrass landscape structure on the juvenile blue crab habitat-survival function. Mar Ecol Prog Ser 300:179-191 
Hovel KA, Lipcius RN (2001) Habitat fragmentation in a seagrass landscape: patch size and complexity control blue crab survival. Ecology 82:1814-1829

Hovel KA, Lipcius RN (2002) Effects of seagrass habitat fragmentation on juvenile blue crab survival and abundance. J Exp Mar Biol Ecol 271:75-98

Hovel KA, Fonseca MS, Myer DL, Kenworthy WJ, Whitfield PE (2002) Effects of seagrass landscape structure, structural complexity and hydrodynamic regime on macrofaunal densities in North Carolina seagrass beds. Mar Ecol Prog Ser 243:11-24

Howard RK, Koehn JD (1985) Population dynamics and feeding ecology of pipefish (Syngnathidae) associated with eelgrass beds of Western Port, Victoria. Aust J Mar Freshw Res 36:361-370

Irlandi EA (1997) Seagrass patch size and survivorship of an infaunal bivalve. Oikos 78:511-518

Irlandi EA, Orlando BA, Ambrose WG (1999) Influence of seagrass habitat patch size on growth and survival of juvenile bay scallops Argopecten irradians concentricus (Say). J Exp Mar Biol Ecol 235:21-43

Jackson EL, Rowden AA, Attrill MJ, Bossy SF, Jones MB (2001) The importance of seagrass beds as a habitat for fishery species. Oceanogr Mar Biol Annu Rev 39:269-303

Jackson EL, Rowden AA, Attrill MJ, Bossy SF, Jones MB (2002) Comparison of fish and mobile macroinvertebrates associated with seagrass and adjacent sand at St. Catherine Bay, Jersey (English Channel): emphasis on commercial species. Bull Mar Sci 71:1333-1341

Jelbart JE (2004) The influence of seascape spatial features on the fish and macroinvertebrates in seagrass beds. $\mathrm{PhD}$ thesis, University of Western Sydney

Editorial responsibility: Otto Kinne (Editor-in-Chief), Oldendorf/Luhe, Germany
Kuiter RH (2000) Coastal fishes of south eastern Australia. Gary Allen, Sydney

Laurel BJ, Gregory RS, Brown JA (2003) Predator distribution and habitat patch area determine predation rates on Age0 juvenile cod Gadus spp. Mar Ecol Prog Ser 251:245-254

Levin P, Petrik R, Malone J (1997) Interactive effects of habitat selection, food supply and predation on recruitment of an estuarine fish. Oecologia 112:55-63

McNeill SE, Fairweather PG (1993) Single large or several small marine reserves? An experimental approach with seagrass fauna. J Biogeogr 20:429-440

Peterson GW, Turner RE (1994) The value of salt marsh edge versus interior as a habitat for fish and decapod crustaceans in a Louisiana tidal marsh. Estuaries 17: $235-262$

Sanchez-Jerez P, Cebrian CB, Espla AAR (1999) Comparison of the epifauna spatial distribution in Posidonia oceanica, Cymodocea nodosa and unvegetated bottoms: importance of meadow edges. Acta Oecol 20:391-405

Schumaker NH (1996) Using landscape indices to predict habitat connectivity. Ecology 77:1210-1225

Short FT, Wyllie-Echeverria S (1996) Natural and human induced disturbances of seagrasses. Environ Conserv 23: $17-27$

Sogard SM (1989) Colonisation of artificial seagrass by fishes and decapod crustaceans-Importance of proximity to natural eelgrass. J Exp Mar Biol Ecol 133:15-37

Tanner JE (2004) Edge effects in fragmented seagrass meadows. Aust Ecol 30:210-218

Virnstein RW, Curran MC (1986) Colonisation of artificial seagrass versus time and distance from source. Mar Ecol Prog Ser 29:279-288

Submitted: August 11, 2005; Accepted: January 25, 2006 Proofs received from author(s): July 21, 2006 